\title{
Pengaruh Likuiditas dan Profitabilitas Terhadap Nilai Perusahaan
}

\author{
Choirul Iman ${ }^{1}$, Fitri Nurfatma Sari ${ }^{2}$, Nanik Pujiati ${ }^{3}$ \\ 1,2,3 Fakultas Ekonomi dan Bisnis, Universitas Budi Luhur Jakarta \\ e-mail: ${ }^{1} 1932600107 @$ student.budiluhur.ac.id, ${ }^{2} 1932600131 @$ student.budiluhur.ac.id, \\ ${ }^{3} 1932600123 @$ student.budiluhur.ac.id

\begin{tabular}{ccc}
\hline Diterima & Direvisi & Disetujui \\
$19-09-2021$ & $02-10-2021$ & $03-10-2021$ \\
\hline
\end{tabular}

\begin{abstract}
Abstrak - Terjadinya penurunan laba pada beberapa perusahaan makanan dan minuman pada kuartal I tahun 2019 begitupula pada tahun 2020, kinerja industri mengalami penurunan pada masa penerapan PSBB. Permasalahan yang terjadi di industri tersebut lebih terkait dengan pelemahan dari sisi demand, dimana untuk konsumen kelas menengah atas lebih menahan pengeluaran sementara konsumen menengah bawah sebagai market terbesar tidak memiliki cash untuk berbelanja. Penelitian ini bertujuan untuk menguji pengaruh variabel likuiditas dan profitabilitas terhadap variabel nilai perusahaan. Terdapat dua hipotesis yang diuji dalam penelitian ini. Hipotesis pertama likuiditas berpengaruh positif terhadap nilai perusahaan dan hipotesisis kedua profitabilitas berpengaruh positif terhadap nilai perusahaan. Penelitian ini menggunakan 15 perusahaan makanan dan minuman yang terdaftar di Bursa Efek Indonesia, dipilih menggunakan metode purposive random sampling dari periode tahun 2016 sampai dengan tahun 2020. Metode statistik yang digunakan untuk menguji hipotesis adalah SEM-PLS (Structural Equation Model - Partial Least Square). Hasil penelitian menunjukkan bahwa variabel likuiditas dan profitabilitas berpengaruh positif dan signifikan terhadap variabel nilai perusahaan.
\end{abstract}

Kata Kunci: Likuiditas, Profitabilitas, Nilai Perusahaan.

Abstraction - There was a decline in profits for several food and beverage companies in the first quarter of 2019 as well as in 2020, industrial performance decreased during the PSBB implementation period. The problems that occur in the industry are more related to the weakening of the demand side, where the upper middle class consumers are more restrained in spending while the lower middle class consumers as the largest market do not have cash to shop. This research aims to examine the effect of liquidity and profitability variables on firm value variables. There are two hypotheses tested in this study. The first hypothesis is that liquidity has a positive effect on firm value and the second hypothesis that profitability has a positive effect on firm value. This study uses 15 Food and Beverage companies listed on the Indonesia Stock Exchange, selected using the purposive random sampling method from the period 2016 to 2020. The statistical method used to test the hypothesis is SEM-PLS (Structural Equation Model - Partial Least Square). The results showed that the liquidity and profitability variables had a positive and significant effect on firm value variables.

Keywords: Liquidity, Profitability, Firm Value.

\section{PENDAHULUAN}

Kondisi ekonomi saat ini telah menciptakan persaingan yang ketat antara perusahaan dengan perusahaan lainnya. Salah satu industri di dalamnya adalah perusahaan yang bergerak dalam industri barang konsumsi makanan dan minuman. Sepanjang tahun 2020, kinerja industri makanan dan minuman mengalami penurunan kinerja di masa penerapan PSBB (Pembatasan Sosial Berskala Besar). Permasalahan yang terjadi di industri tersebut lebih terkait dengan pelemahan dari sisi demand, dimana untuk konsumen kelas menengah atas lebih menahan pengeluaran sementara konsumen menengah bawah sebagai market terbesar tidak memiliki cash untuk berbelanja. Persaingan membuat setiap perusahaan menjadi lebih meningkatkan kinerja perusahaannya, sehingga tujuan perusahaan dapat tercapai. Tujuan utama perusahaan adalah meningkatkan kemakmuran bagi pemilik atau pemegang saham dengan cara meningkatkan nilai perusahaan (Tahu \& Susilo, 2017).

Nilai perusahaan merupakan salah satu konsep penting yang dipertimbangkan oleh investor dalam menilai investasinya. Nilai perusahaan merupakan indikator bagaimana pasar menilai perusahaan secara komprehensif. Nilai perusahaan tercermin dari harga pasar saham perusahaan. Semakin tinggi nilai pasar saham perusahaan mengindikasikan minat yang tinggi bagi investor untuk berinvestasi pada perusahaan dimaksud. Semakin tinggi nilai perusahaan, semakin tinggi pula kesejahteraan yag dinimati oleh inestor (Suroto, 2015). Pada kuartal I 2019 terjadi penurunan laba pada beberapa perusahaan makanan dan minuman, bahkan yang menjadi market leader di 
sektornya seperti PT. Unilever Indonesia Tbk, PT. Mayora Indah Tbk dan PT. Garudafood Putra Putri Jaya Tbk. Laba bersih ketiga perusahaan tersebut mengalami penurunan sebesar $4,37 \%$ untuk PT. Unilever Indonesia Tbk, 0,51\% untuk PT. Mayora Indah Tbk dan paling besar dialami oleh PT. Garudafood Putra Putri Jaya Tbk yaitu pada 19,9\%.

Profitabilitas memiliki hubungan terhadap nilai perusahaan karena semakin banyak keuntungan yang dihasilkan dari aset yang dimilikinya, maka para pemegang saham atau investor akan lebih tertarik karena prospek perusahaan dalam menghasilkan keuntungan yang tinggi, sehingga nantinya return yang akan didapatkannya juga tinggi. Kondisi ini akan membuat banyak permintaan saham yang berdampak pada naiknya harga yang mencerminkan nilai perusahaan yang tinggi (Yanti \& Abundanti, 2019). Dalam beberapa penelitian sebelumnya profitabilitas memiliki hubungan dan pengaruh terhadap nilai perusahaan dengan hasil yang bervariasi dan sebagian besar menunjukkan hasil positif dan signifikan (Harun \& Jeandry, 2018; Oktrima, 2017; Regia Rolanta et al., 2020; Yanti \& Abundanti, 2019).

Likuiditas merupakan rasio yang menggambarkan kemampuan perusahaan dalam memenuhi kewajiban jangka pendeknya secara tepat waktu (Fahmi, 2012). Artinya apabila perusahaan timbul tagihan hutang maka akan mampu memenuhi hutang tersebut. Jika perusahaan memiliki kemampuan untuk melunasi kewajiban jangka pendeknya pada saat jatuh tempo maka perusahaan tersebut merupakan perusahaan yang likuid dan begitupula sebaliknya. Penelitian sebelumnya mengkaitkan likuiditas dengan nilai perusuhaan (Harun \& Jeandry, 2018; Mardiyati et al., 2015; Oktrima, 2017; Regia Rolanta et al., 2020). Semakin tinggi likuiditas perusahaan akan berdampak pada kepercayaan investor untuk menginvestasikan dananya di perusahaan yang bersangkutan. Penelitian ini ditujukan untuk menguji pengaruh likuditas dan profitabilitas terhadap nilai perusahaan.

\section{Agency Theory}

Teori agensi sebagai agen yang dalam hal ini adalah manajemen yang mengelola suatu perusahaan, dan yang disebut sebagai prinsipel adalah pemegang saham. Manajer cenderung mengutamakan kepentingan pribadi. Hal tersebut membuat adanya konflik antara pemegang saham dengan manajer yang akan mengakibatkan keuntungan menurun. Akibatnya, terdapat masalahmasalah keagenan (Agency Problems).

Dalam hubungan keagenan, manajemen diharapkan dapat mengambil keputusan perusahaan terutama kebijakan keuangan yang menguntungkan pemilik perusahaan dan stakeholder. Dalam hal keputusan yang dilakukan oleh manajemen (agent) merugikan perusahaan (pemegang saham principal) maka terjadi agency problem (Ismiyanti \& Mamduh, 2003). Alasan digunakan teori ini karena adanya konflik kepentingan antara shareholder dan manajer, dimana shareholder mengharapkan kesejahteraan atas perusahaan tersebut namun disisi lain manajer yang seharusnya membuat keputusan dengan tujuan memaksimalkan kesejahteraan para pemegang saham, bisa juga manajer tidak selalu bertindak demi kepentingan shareholder. Memaksimalkan kesejahteraan para pemegang saham berarti manajemen harus memaksimalkan nilai perusahaan, dimana tingkat keberhasilan perusahaan yang sering dikaitkan dengan harga saham. Harga saham yang tinggi membuat nilai perusahaan juga tinggi dan nilai perusahaan yang tinggi akan membuat pasar percaya tidak hanya pada kinerja keuangan perusahaan saat ini namun pada prospek perusahaan dimasa yang akan datang.

\section{Signalling Theory}

Pada teori sinyal dijelaskan alasan mengapa perusahaan harus memberikan informasi berupa laporan keuangan kepada pihak luar (investor dan kreditor). Hal tersebut dikarenakan terdapat asimetri informasi antara perusahaan dan pihak eksternal. Hal ini dikarenakan perusahaan mengetahui lebih banyak informasi dan prospek yang akan datang daripada pihak eksternal. Perusahaan dapat meningkatkan nilai perusahaan dengan cara mengurangi asimetri informasi dan salah satu cara untuk mengurangi asimetri informasi adalah dengan memberikan sinyal kepada pihak eksternal berupa informasi keuangan yang handal dan akan mengurangi ketidakpastian mengenai prospek perusahaan yang akan datang (Wolk et al., 2001) dalam (Sari \& Zuhrohtun, 2006).

Sebagai hasil dari tanda waktu yang lebih baik ini, investor membeli banyak saham yang menyebabkan kenaikan harga saham saat ini. Alasan digunakannya signalling theory dalam penelitian ini didasari dugaan bahwa profitabilitas, likuiditas mampu memberi sinyal pada stakeholder tentang naik/ turunnya nilai perusahaan. Sinyal ini akan memberi tanda bagi investor untuk membeli/ menjual saham yang menyebabkan kenaikan/ penurunan harga saham.

\section{Nilai Perusahaan}

Nilai perusahaan merupakan konsep yang penting bagi pemegang saham atau investor karena merupakan indikator untuk menilai perusahaan secara keseluruhan yang tercermin pada harga saham perusahaan. Nilai perusahaan merupakan indikator bagaimana pasar menelai perusahaan secara komprehensif. Nilai perusahaan tercermin dari harga pasar saham perusahaan. Semakin tinggi nilai pasar saham perusahaan mengindikasikan minat yang tinggi bagi investor untuk berinvestasi pada perusahaan dimaksud. Semakin tinggi nilai perusahaan, semakin tinggi pula kesejahteraan yag dinimati oleh inestor (Suroto, 2015). Nilai perusahaan diukur dengan Tobin's Q dan Price Book Value (PBV).

Rasio Tobin's Q merupakan rasio nilai pasar modal terhadap penggantian biaya dan mengukur 
semua peluang investasi perusahaan yang diukur dengan rumus sebagai berikut:

$Q=\frac{M V S+D}{\text { Total Asset }}$

Sumber: Dzahabiya et al. (2020)

Keterangan:

$\mathrm{Q} \quad=$ Nilai Perusahaan

MVS = Jumlah saham yang beredar $\mathrm{x}$ harga saham akhir tahun

D $\quad=$ (Kewajiban lancar - aktiva lancar $)+$ hutang jangka panjang

TA $=$ Total Aktiva

Price Book Value (PBV) digunakan untuk mengukur nilai yang diberikan pasar keuangan kepada manajemen dan organisasi perusahaan sebagai sebuah perusahaan yang terus tumbuh yang diukur dengan rumus sebagai berikut:

$P B V=\frac{\text { Harga Pasar per lembar Saham }}{\text { Nilai Buku per lembar Saham }}$

Sumber: Ariyanti dan Putra (2018)

Keterangan:

Harga pasar per lembar saham = closing price saham Nilai buku per lembar saham = Total Ekuitas: Jumlah saham beredar.

\section{Likuditas}

Menurut Hery (2019) likuiditas adalah kemampuan perusahaan dalam memenuhi kewajiban atau membayar hutang jangka pendeknya. Dengan kata lain rasio likuiditas merupakan rasio yang dapat digunakan untuk mengukur tingkat kemampuan perusahaan dalam melunasi kewajiban jangka pendeknya yang akan jatuh tempo. Jika perusahaan memiliki kemampuan untuk melunasi kewajiban jangka pendeknya pada saat jatuh tempo maka perusahaan tersebut termasuk perusahaan yang likuid dan begitupun sebaliknya. Untuk dapat memenuhi kewajiban jangka pendeknya, perusahaan harus memiliki tingkat ketersediaan jumlah kas yang baik atau aset lancar lainnya yang juga dapat dengan segera dikonversi atau diubah menjadi kas. Penelitian ini dapat diproksikan dengan menggunakan current ratio (CR) dan cash ratio (CAR).

Current ratio (rasio lancar) adalah rasio yang digunakan untuk mengukur kemampuan perusahaan dalam memenuhi kewajiban jangka pendeknya yang segera jatuh tempo dengan menggunakan total aset lancar yang dimiliki. Current ratio mengindikasikan kecukupan aktiva lancer yang dimiliki perusahaan untuk membayar kewajiban yang jatauh tempo. Current ratio dapat dirumuskan sebagai berikut:

$C R=\frac{\text { Asset Lancar }}{\text { Kewajiban Lancar }}$

Sumber: Hery (2018:161)

Cash ratio adalah rasio yang digunakan untuk mengukur seberapa besar uang kas atau setara kas yang tersedia untuk membayar hutang jangka panjang, sehingga ratio ini dapat menggambarkan kemampuan perusahaan dalam melunasi kewajiban lancarnya yang akan segera jatuh tempo. Dirumuskan sebagai berikut:

$C A R=\frac{\text { Kas dan setara } k a s}{\text { Kewajiban Lancar }}$

Sumber: Hery (2018:161)

\section{Profitabilitas}

Profitabilitas adalah kemampuan perusahaan menggunakan modal kerja untuk menghasilkan laba, sehingga perusahaan tidak mengalami kesulitan dalam mengembalikan hutangnya baik hutang jangka pendek maupun hutang jangka panjang serta pembayaran dividen kepada investor yang menanamkan modalnya pada perusahaan tersebut (Harun \& Jeandry, 2018). Semakin tinggi laba yang diperoleh perusahaan maka semakin besar tingkat pembayaran dividen yang dibagikan kepada pemegang saham.

Rasio profitabilitas dapat digunakan sebagai alat untuk mengukur tingkat efektivitas kinerja manajemen dalam menghasilkan laba yang maksimal bagi perusahaan. Pada penelitian ini Profitabilitas di proksikan dengan return on assets (ROA) dan return on equity (ROE).

$$
\text { Menurut Kasmir (2016:201) ROA }
$$
merupakan rasio yang menunjukan return atas jumlah aktiva yang digunakan dalam perusahaan. Rumus yang dapat digunakan untuk menghitung return on assets adalah sebagai berikut:

$$
R O A=\frac{\text { Laba Bersih }}{\text { Total Asset }}
$$

Sumber: Oktrima (2017).

Return On Equity merupakan rasio perbandingan laba bersih setelah pajak yang dibandingkan dengan total ekuitas yang mana total ekuitas ini berasal dari pendapatan (income) yang ada bagi para pemilik perusahaan. Meskipun pemilik tersebut merupakan pemegang saham preferen maupun pemegang saham biasa atas modal yang telah diinvestasikan di perusahaan tersebut (Harahap, 2008:305). Return on equity ini menunjukkan kemampuan perusahaan didalam mengelola modalnya sendiri atau disebut dengan net worth, yang mana secara efektif dan mengukur tingkat laba dari investasi yang telah dilakukan pemilik modal atau pemegang saham (Agnes, 2009:20). Return on equity mengambarkan rentabilitas modal atau yang juga disebut sebagai rentabilitas usaha. Sedangkan rumus untuk return on equity adalah:

$$
R O E=\frac{\text { Laba Bersih }}{\text { Total Ekuitas }}
$$

Sumber : Hery (2018:195). 


\section{Kerangka Penelitian}

Kerangka penelitian adalah penjelasan sementara terhadap gejala yang menjadi objek permasalahan yang selanjutnya dianalisis secara kritis sehingga menghasilkan sintesa hubungan antar variabel penelitian.

Kasmir (2012) menyatakan bahwa likuiditas merupakan rasio yang menggambarkan kemampuan perusahaan untuk memenuhi kewajiban jangka pendeknya. Fungsi dari rasio likuiditas adalah untuk menunjukkan atau mengukur kemampuan perusahaan untuk memenuhi kewajiban yang jatuh tempo, baik kewajiban kepada pihak di luar perusahaan maupun di dalam perusahaan. Rasio likuiditas atau sering disebut rasio modal kerja merupakan rasio yang mengukur kemampua perusahaan dalam memenuhi kewajiban jangka pendeknya. Likuiditas dapat diukur dengan current ratio dan cash ratio.

Profitabilitas adalah hasil yang diperoleh melalui upaya manajemen terhadap dana yang diinvestasikan oleh pemilik dan investor. Semakin tinggi laba atau profitabilitas yang diperoleh perusahaan, semakin baik untuk nilai perusahaan tersebut. Profitabilitas dapat diukur menggunakan ROA (Return on Assets) dan ROE (Return On Equity).

Berdasarkan landasan teori yang telah diuraikan dan diringkas dari hasil penelitian sebelumnya, berikut ini model kerangka pemikiran penelitan mengenai analisis likuiditas dan profitabilitas terhadap nilai perusahaan.

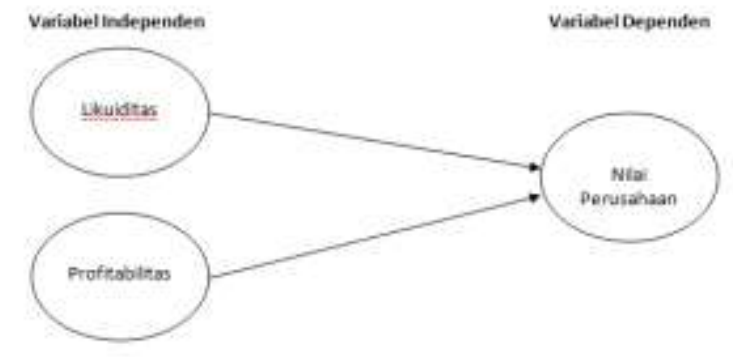

Sumber: Data diolah sendiri

Gambar 1: Kerangka Konseptual Penelitian

\section{Hipotesis Penelitian}

Menurut (Priyatno, 2010) "hipotesis merupakan jawaban sementara terhadap permasalah yang diteliti (yang telah ditetapkan, dirumuskan, dan diidentifikasi)". Disebut sementara karena bersifat rasional atau logis sebagai hasil deduktif yang belum tentu benar (perlu diuji secara empiris) selain itu hipotesis juga dapat dinyatakan sebagai jawaban teoritis terhadap rumusan masalah penelitian dan belum merupakan jawaban yang empiris.

\section{Pengaruh Likuiditas terhadap Nilai Perusahaan}

Sudiani \& Darmayanti, (2016) menyatakan bahwa likuiditas merupakan kemampuan suatu perusahaan untuk memenuhi jangka pendeknya yang telah jatuh tempo. Menurut hasil penelitian likuiditas berhubungan positif terhadap nilai perusahaan. Semakin tinggi nilai likuiditas maka akan semakin tinggi pula nilai perusahaan dan semakin rendah likuiditas maka nilai perusahaan rendah. Beberapa penelitian sebelumnya mengkaitkan likuiditas dengan nilai perusahaan (Harun \& Jeandry, 2018; Oktrima, 2017; Regia Rolanta et al., 2020). Kemampuan kas yang tinggi pada perusahaan akan berdampak pada kemampuan perusahaan dalam memenuhi kewajiban jangka pendeknya, yang akan berdampak positif terhadap nilai perusahaan.

H1: Likuiditas berpengaruh positif terhadap Nilai Perusahaan

\section{Pengaruh Profitabilitas terhadap Nilai Perusahaan}

Profitabilitas adalah kemampuan perusahaan dalam memperoleh laba. Perusahaan yang memiliki tingkat profitabilitas yang tinggi dapat diartikan juga bahwa perusahaan tersebut memiliki tingkat penjualan atau pendapatan yang tinggi. Beberapa penelitian sebelumnya mengkaitkan proftabilitas dengan nilai perusahaan (Fajaria, 2018; Jihadi et al., 2021; Kalbuana, N., Prasetyo, B., Kurnianto, B., \& Saputro, 2020; Mardiyati et al., 2015; Pratiwi et al., 2020; Regia Rolanta et al., 2020; Reschiwati et al., 2020; Runis et al., 2021; Sari, 2020; Sitepu \& Wibisono, 2020; Tahu \& Susilo, 2017; Yanti \& Abundanti, 2019; Zuhroh, 2019). Semakin besar profitabilitas perusahaan maka semakin menarik minat investor dalam menanamkan saham pada perusahaan tersebut, dengan harapan para investor mendapatkan keuntungan maka nilai perusahaan tersebut akan semakin besar. Menurut hasil penelitian Purnomo \& Erawati, (2019) bahwa terdapat pengaruh yang positif dan signifikan antara variabel profitabilitas terhadap nilai perusahaan.

$\mathrm{H} 2$ : Profitabilitas berpengaruh positif terhadap nilai perusahaan

\section{METODE PENELITIAN}

Metodologi penelitian adalah suatu teknik atau cara mencari, memperoleh, mengumpulkan atau mencatat data, baik berupa data primer maupun data sekunder yang digunakan untuk keperluan menyusun suatu karya ilmiah kemudian menganalisa faktor-faktor yang berhubungan dengan pokokpokok permasalahn sehingga akan terdapat suatu kebenaran data-data yang akan diperoleh.

Metode dalam penelitian ini menggunakan pendekatan kuantitatif. Menurut (Widiyanto, 2013) "Pendekatan kuantitatif adalah data yang diperoleh berupa angka-angka atau data kuantitatif yang diangkakan tersebut diolah, diinterpretasi dan ditarik kesimpulan dan diambil kesimpulan". 
SEM-PLS (Structural Equation Model Partial Least Square) akan digunakan untuk menganalisa data yang dihasilkan. Penggunaan SEMPLS dikarenakan jumlah sampel dalam penelitian ini sedikit (kurang dari 100 sampel). SEM (Structural Equation Model ) adalah model persamaan struktural dengan analisis multivariate yang memungkinkan untuk menguji hubungan antar variabel yang kompleks baik recursive maupun non-recursive untuk memperoleh gambaran menyeluruh mengenai keseluruhan model.

PLS (Partial Least Square) adalah model persamaan struktural (SEM) yang berbasis komponen atau varian (variance). Menurut Ghozali \& Latan (2020) "PLS merupakan pendekatan alternatif yang bergeser dari pendekatan SEM berbasis kovarian menjadi berbasis varian". SEM yang berbasis kovarian umumnya menguji kausalitas/teori, sedangkan PLS lebih bersifat predictive model. Selain dapat digunakan untuk mengkorfimasi teori, PLS juga dapat digunakan untuk menjelaskan ada tidaknya hubungan antar variabel laten. PLS dapat sekaligus menganalisis konstruk yang dibentuk dengan indikator reflektif dan formatif. Hal ini tidak dapat dilakukan oleh SEM yang berbasis kovarian karena akan menjadi unidentified model. Menurut Ghozali \& Latan (2020) tujuan PLS adalah membantu peneliti untuk tujuan prediksi.

Penelitian ini memiliki dua variabel independen yaitu variabel likuiditas dan profitabilitas. Variabel likuiditas menggunakan indikator current ratio dan cash ratio sedangkan profitabilitas menggunakan indikator return on assets (ROA) dan return on Equity (ROE). Dengan variabel dependen yaitu nilai perusahaan yang menggunakan indikator Tobin's Q dan Price Book Value (PBV).

Dengan menggunanakan metode purposive random sampling terdapat 15 (lima belas) perusahaan makanan dan minuman yang terdaftar di Bursa Efek Indonesia pada tahun 2016 sampai dengan tahun 2020 yang telah memenuhi syarat penelitian.

\section{HASIL DAN PEMBAHASAN}

Penelitian ini ditujukan untuk menguji pengaruh likuiditas dan profitabilitas terhadap nilai perusahaan. Hasil pengujian dengan SmartPLS Algorytm dapat dilihat pada gambar dan tabel di bawah ini:

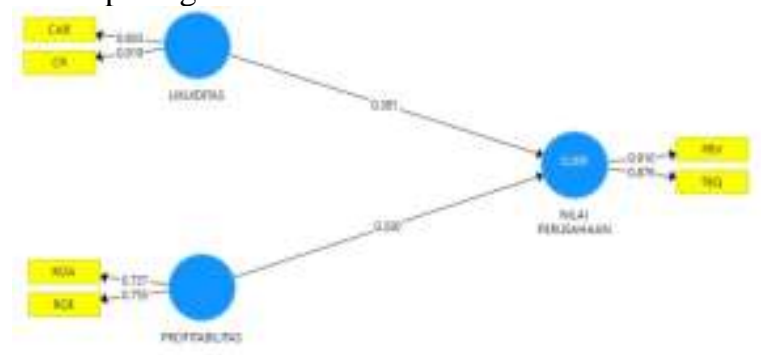

Sumber: Hasil SmartPLS

Gambar 2: Hasil Pengujian dengan SmartPLS
Berdasarkan Gambar 2 menerangkan bahwa CAR dan CR mampu merefleksikan likuiditas dengan nilai outer loadings masing-masing sebesar 0,933 dan 0,919 . Profitabilitas dijelaskan oleh dua indikator yaitu ROA dan ROE senilai 0,737 dan 0,753 . PBV dan TBQ mampu merefleksikan nilai perusahaan dengan nilai outer loadings sebesar 0,910 dan 0,876 sehingga semua indikator telah memenuhi ketentuan convergent validity. Menurut (Ghozali \& Latan, 2020) "convergent validity adalah measurement model dengan indikator refleksif dapat dilihat dari korelasi antara score item/indikator dengan score konstruknya. Indikator individu dianggap reliable jika memiliki nilai korelasi diatas 0,70 ”.

Hasil pengujian hipotesis dengan SmartPLS Bootstrapping dapat dilihat pada tabel di bawah ini:

Tabel 1: Hasil Pengujian Pengujian Hipotesis

\begin{tabular}{lccccl}
\hline Variabel & $\begin{array}{c}\text { Original } \\
\text { Sample }\end{array}$ & $\begin{array}{c}\text { Std } \\
\text { Deviasi }\end{array}$ & $\begin{array}{c}\mathrm{T} \\
\text { Statistic } \\
>1,96\end{array}$ & $\begin{array}{c}\mathrm{P} \\
\text { Values } \\
<0,05\end{array}$ & Ket \\
\hline $\begin{array}{l}\text { Likuidita } \\
\text { S -> Nilai }\end{array}$ & 0,381 & 0,069 & 5,552 & 0,000 & $\begin{array}{l}\text { Positi } \\
\mathrm{f}\end{array}$ \\
$\begin{array}{l}\text { Perusaha } \\
\text { an }\end{array}$ & & & & & $\begin{array}{l}\text { Signif } \\
\text { ikan }\end{array}$ \\
\hline $\begin{array}{l}\text { Profitabil } \\
\text { itas -> }\end{array}$ & 0,230 & 0,083 & 2,784 & 0,006 & $\begin{array}{l}\text { Positi } \\
\text { Nilai }\end{array}$ \\
$\begin{array}{l}\text { Perusaha } \\
\text { an }\end{array}$ & & & & & f \\
Signif \\
ikan
\end{tabular}

Sumber: Hasil SmartPLS

Berdasarkan tabel diatas likuiditas memiliki nilai $\mathrm{T}$ statistic sebesar 5,552>1.96 dengan nilai koefisien sebesar 0,381 berarti likuiditas berpengaruh terhadap nilai perusahaan dan signifikan pada 0.000 $(<0,05)$, yang artinya semakin tinggi nilai likuiditas maka akan tinggi nilai perusahaan begitupun sebaliknya. Kuswanta (2016) menyatakan bahwa likuiditas menunjukkan kemampuan suatu perusahan untuk memenuhi kewajiban jangka pendek atau kewajiban yang telah jatuh tempo. Likuiditas merupakan rasio yang menggambarkan kemampuan perusahaan dalam memenuhi kewajiban jangka pendeknya secara tepat waktu (Fahmi, 2012). Kemampuan kas yang tinggi akan berdampak terhadap kemampuan kewajiban jangka pendek perusahaan dan berdampak positif pada nilai perusahaan.

Dalam teori sinyal, likuiditas mencerminkan ketersediaan dana yang dimiliki perusahaan guna memenuhi semua hutang yang akan jatuh tempo. Perusahaan yang semakin besar memiliki likuiditas yang semakin besar yang berarti memiliki aset lancar yang lebih untuk membiayai kegiatan operasionalnya. Dengan semakin baik likuiditas perusahaan menandakan bahwa perusahaan tersebut sanggup dalam membayarkan hutang yang akan jatuh tempo dan perusahaan tersebut akan dipandang baik oleh investor sehingga banyak investor yang menanamkan saham di perusahaan tersebut, menjadikan harga 
saham perusahaan meningkat maka nilai perusahaan tersebut akan meningkat Sudiani dan Darmayanti (2016) dan Uli dkk (2020) yang menyatakan bahwa likuiditas dapat mempengaruhi nilai perusahaan. Namun menurut Manurung dan Herijawati (2016) dan Lumoly dkk (2018) bahwa likuiditas tidak mempengaruhi nilai perusahaan.

Profitabilitas memiliki nilai $\mathrm{T}$ statistic sebesar 2,784 > 1.96 dengan nilai koefisien sebesar 0,230 berarti profitabilitas berpengaruh terhadap nilai perusahaan dan signifikan pada $0.006(<0,05)$, yang artinya besar kecilnya Profitabilitas mempengaruhi nilai Oerusahaan.

Profitabilitas bagi perusahaan merupakan kemampuan perusahaan dalam penggunaan modal kerja tertentu untuk menghasilkan laba tertentu sehingga perusahaan tidak mengalami kesulitan dalam mengembalikan utang- utangnya baik utang jangka pendek maupun utang jangka panjang serta pembayaran dividen bagi para investor yang menanamkan modalnya pada perusahaan tersebut (Harun \& Jeandry, 2018). Profitabilitas merupakan rasio yang dapat mewakili kinerja keuangan perusahaan, dimana meningkatnya profitabilitas perusahaan akan meningkatkan return yang akan didapatkan oleh investor. Semakin tinggi laba yang diperoleh perusahaan maka semakin besar tingkat pembayaran dividen yang dibagikan kepada pemegang saham sehingga dapat memicu kenaikan permintaan saham. Penelitian ini sejalan dengan Sudiani dan Darmayanti (2016) dan Purnomo dan Erawati (2019) yang menyatakan bahwa profitabilitas dapat mempengaruhi nilai perusahaan. Namun tidak sejalan dengan penelitian Tarima dkk (2016) dan Sondakh (2019) yang menyatakan bahwa profitabilitas tidak berpengaruh terhadap nilai perusahaan.

\section{KESIMPULAN}

Kondisi ekonomi saat ini telah menciptakan persaingan yang ketat antara perusahaan dengan perusahaan lainnya. Persaingan membuat setiap perusahaan menjadi lebih meningkatkan kinerja perusahaannya, sehingga tujuan perusahaan dapat tercapai. Penelitian ini fokus meneliti pengaruh likuiditas dan profitabilitas terhadap nilai perusahaan, pada perusahaan yang bergerak dalam bidang makanan dan minuman periode 2016 sampai dengan 2020. Berdasarkan hasil penelitian, maka penelitian ini dapat ditarik kesimpulan bahwa variabel likuiditas berpengaruh positif dan signifikan terhadap nilai perusahaan begitupula variabel profitabilitas terdapat pengaruh yang positif dan signifikan terhadap nilai perusahaan. Data penelitian ini masih terbatas, sehingga peneliti selanjutnya dapat mengembangkan data penelitian tidak hanya terpaut pada sektor makanan dan minuman saja. Dan peneliti selajutnya dapat menambahkan varibel-variabel lain yang mempengaruhi nilai perusahaan selain dari variabel dalam penelitian ini sehingga hasil yang dihasilkan akan lebih representatif.

\section{REFERENSI}

Agnes, Sawir. 2009. Analisa Kinerja Keuangan dan Perencanaan keuangan Perusahaan. Jakarta: PT. Gramedia Pustaka Utama Arianti dan Putra. (2018).

Fahmi, Irham. 2012. Analisis Kinerja Keuangan. Bandung: Alfabeta

Fajaria, A. Z. (2018). The Effect of Profitability, Liquidity, Leverage and Firm Growth of Firm Value with its Dividend Policy as a Moderating Variable. International Journal of Managerial Studies and Research, 6(10), 55-69. https://doi.org/10.20431/2349-0349.0610005

Ghozali, I. \& Latan, H. 2020. Partial Least Square : Konsep, Teknik dan Aplikasi SmartPLS 2.0 M3. Semarang: Badan Penerbit Universitas Diponegoro.

Harahap, Sofyan Syafri. 2008. Analisis Kritis atas Laporan Keuangan. Jakarta: PT Raja Grafindo Persada.

Harun, S., \& Jeandry, G. (2018). Pengaruh Profitabilitas, Free Cash Flow, Leverage, Likuiditas Dan Size terhadap Dividen Payout Ratio (DPR) pada Perusahaan Manufaktur yang terdaftar di Bursa Efek Indonesia. Jurnal Riset Akuntansi, 5(2), 122-137. https://ejournal.unkhair.ac.id/index.php/trust/ar ticle/view/960/718

Hemastuti, C. P., \& Hermanto, S. B. 2014. Pengaruh Profitabilitas, Kebijakan Dividen, Kebijakan Hutang, Keputusan Investasi Dan Kepemilikan Insider Terhadap Nilai Perusahaan. Jurnal Ilmu \& Riset Akuntansi, Vol.3(No.4), $1-\quad 15$. https://core.ac.uk/download/pdf/151518024. pdf

Hery. 2018. Analisis Laporan Keuangan: Integrated and Comprehensive Edition. Cetakan Ketiga. PT. Gramedia: Jakarta.

2019. Manajemen Kinerja. Jakarta: PT Grasindo.

Ismiyanti, Fitri dan M.M. Hanafi. 2003. Kepemilikan Manajerial, Kepemilikan Institusional, Risiko, Kebijakan Utang dan Kebijakan Dividen: Analisis Persamaan Simultan. Prosiding Simp. http://etd.repository.ugm.ac.id/penelitian/det ail/21437

Jihadi, M., Vilantika, E., Hashemi, S. M., Arifin, Z., Bachtiar, Y., \& Sholichah, F. (2021). The Effect of Liquidity, Leverage, and Profitability on Firm Value: Empirical Evidence from Indonesia. Journal of Asian Finance, Economics and Business, 8(3), 423-431. https://doi.org/10.13106/jafeb.2021.vol8.no3.0 423

Kalbuana, N., Prasetyo, B., Kurnianto, B., \& Saputro, 
R. (2020). Liquidity Effect, Profitability Leverage to Company Value: A Case Study Indonesia. European Journal of Molecular \& Clinical Medicine, 7(11), 2800-2822. https://ejmcm.com/article_6290.html

Kasmir. (2009). Bank dan Lembaga Keuangan lainnya. Edisi Revisi 2008. Jakarta, Rajawali Pers.

(2012). Analisis Laporan Keuangan. Jakarta : PT. Raja Grafindo Persada.

(2016). Analisis Laporan Keuangan. Jakarta: PT. Raja Grafindo Persada.

Kuswanta, T. (2016). Pengaruh Leverage, Profitabilitas, dan Ukuran Perusahaan yang Terdaftar di Indeks Kompas 100. Jurnal Ilmu Manajemen, 13(2), 162-174. https://journal.uny.ac.id/index.php/jim/articl e/view/25528

Lumoly, Selin et al. (2018). Pengaruh Likuiditas, Ukuran Perusahaan dan Profitabilitas Terhadap Nilai Perusahaan. Jurnal EMBA. Vol. 6 No. 3 Juli 2018. Hal 1108-1117. https://ejournal.unsrat.ac.id/index.php/emba/ar ticle/view/20072

Manurung, M. S., \& Herijawati, E. (2016). Pengaruh Likuiditas Dan Profitabilitas Terhadap Nilai Perusahaan (Study Empiris Pada Perusahaan Manufaktur Sektor Logam Dan Sejenisnya Yang Terdaftar Di Bursa Efek Indonesia). Jurnal Ilmiah Akuntansi Dan Teknologi, 8(2), $1-6$.

https://jurnal.ubd.ac.id/index.php/akunto/article /download/112/68

Mardiyati, U., Nur Utami, S. G., \& Ahmad, G. N. (2015). the Effect of Profitability, Liquidity, Leverage and Firm Size Toward Bond Rating on Non Financial Institution Listed in Indonesia Stock Exchange Period 2010-2014. JRMSI Jurnal Riset Manajemen Sains Indonesia, 6(2), 579-598.

https://doi.org/10.21009/jrmsi.006.2.05

Oktrima, B. (2017). Pengaruh Profitabilitas, Likuiditas, dan Struktur modal terhadap Nilai Perusahaan (Studi Empiris: PT. Mayora Indah, Tbk. Tahun 2011 - 2015). Jurnal Sekuritas Manajemen Keuangan, 1(1), 98-107. http://openjournal.unpam.ac.id/index.php/SKT/ article/view/622

Pratiwi, H., Andri, R., Sari, D. P., \& Yengsih, R. M. (2020). the Effect of Liquidity and Working Capital on Corporate. 1(1), 1-7. https://doi.org/10.31933/DIJEFA

Priyatno, Duwi., (2010). SPSS Untuk Analisis Korelasi, Regresi, dan Multivariate. Yogyakarta: Penerbit Gava Media.

Purnomo, E., \& Erawati, T. (2019). Pengaruh Profitabilitas Terhadap Nilai Perusahaan Dengan Struktur Modal Sebagai Variabel Intervening (Studi Kasus pada Perusahaan
Manufaktur yang Terdaftar di Bursa Efek Indonesia Tahun 2012- 2016). Jurnal Akuntansi Dan Keuangan, 1(4), 37-57. https://doi.org/10.24964/japd.v1i1.882

Regia Rolanta, Riana R Dewi, \& Suhendro. (2020). Pengaruh Profitabilitas, Leverage, Likuiditas, Ukuran Perusahaan Dan Kebijakan Dividen Terhadap Nilai Perusahaan. Jurnal Ilmiah Akuntansi Dan Manajemen, 16(2), 57-66. https://doi.org/10.31599/jiam.v16i2.395

Reschiwati, R., Syahdina, A., \& Handayani, S. (2020). Effect of liquidity, profitability, and size of companies on firm value. Utopia y Praxis Latinoamericana, 25(Extra 6), 325-332. https://doi.org/10.5281/zenodo.3987632

Runis, A., Samsul Arifin, D., Masud, A., \& Kalsum, U. (2021). The Influence of Liquidity, Leverage, Company Size and Profitability on Financial Distress. International Journal of Business and Social Science Research, 11-17. https://doi.org/10.47742/ijbssr.v2n6p2

Sari, I. A. G. D. M. (2020). Profitability and liquidity on firm value and capital structure as intervening variable. International Research Journal of Management, IT and Social Sciences, $7(1)$, 116-127. https://doi.org/10.21744/irjmis.v7n1.828

Sari, Ratna Candra dan Zuhrotun. (2006). Keinformatifan Laba di Pasar Obligasi dan Saham : Uji Liquidation Option Hypothesis. Simposium Nasional Akuntansi 9: Padang. blog.umy.ac.id/ervin/files/2012/06/K-AKPM08.pdf

Sitepu, N. R., \& Wibisono, C. H. (2020). Pengaruh Kebijakan Dividen, Kebijakan Leverage dan Profitabilitas terhadap Nilai Perusahaan (Perusahaan Manufaktur yang terdaftar di BEI pada tahun 1009-2013). Publikasi Imiah, 274282. http://e-journal.uajy.ac.id/8708/

Sondakh, Renly. 2019. The Effect of Dividen Policy, Liquidity, Profitability and Firm Size on Firm Value. Jurnal Accountability. Vol. 8 No 2. https://ejournal.unsrat.ac.id/index.php/accounta bility/article/view/24760

Sudiani, N. K. A., \& Darmayanti, N. P. A. (2016). Pengaruh Profitabilitas, Likuiditas, Pertumbuhan, Dan Investment Opportunity Set Terhadap Nilai Perusahaan. E-Journal Manajemen Universitas Udayana, 5(7), 245861.

https://ojs.unud.ac.id/index.php/Manajemen/art icle/download/20349/14754

Suroto. (2015). Pengaruh keputusan Investasi, Keputusan Pendanaan, dan Kebijakan Dividen terhadap Nilai Perusahaan (Studi Empiris pada perusahaan LQ-45 yang terdaftar di Bursa Efek Indonesia periode Februari 2010 - Januari 2015. Jurnal Ilmiah UNTAG Semarang, 4(3), 100 117.

http://jurnal.untagsmg.ac.id/index.php/sa/articl 
e/view/174/0

Tahu, G. P., \& Susilo, D. D. B. (2017). Effect of Liquidity, Leverage and Profitability to The Firm Value (Dividend Policy as Moderating Variable) in Manufacturing Company of Indonesia Stock Exchange. Research Journal of Finance and Accounting, 8(18), 89-98. https://core.ac.uk/display/234632117?utm_sour ce=pdf\&utm_medium=banner\&utm_campaign $=$ pdf-decoration- $\mathrm{v} 1$

Tarima, Grandi et al. (2016). Pengaruh Profitabilitas, Keputusan Investasi Dan Keputusan Pendanaan Terhadap Nilai Perusahaan Farmasi Yang Terdaftar Di Bei Periode 2011-2014. Jurnal Berkala Ilmiah Efisiensi, 16(4), 465-474. https://ejournal.unsrat.ac.id/index.php/jbie/artic le/view/13629

Uli, R., Ichwanudin, W., \& Suryani, E. (2020). Pengaruh Likuiditas Terhadap Nilai Perusahaan Melalui Struktur Modal Dan Profitabilitas. Tirtayasa Ekonomika, 15(2), 321. https://doi.org/10.35448/jte.v15i2.6795

Yanti, P. D. M., \& Abundanti, N. (2019). Pengaruh Profitabilitas, Leverage dan Kebijakan Dividen Terhadap Nilai Perusahaan Properti, Real Estate dan Kontruksi Bangunan. E-Jurnal Manajemen, 8(9), 5632-5651. https://ojs.unud.ac.id/index.php/Manajemen/art icle/view/46854

Widiyanto, M.A. (2013). Statistika Terapan, Konsep dan Aplikasi SPSS/Lisrel dalamPenelitian Pendidikan, Psikologi dan Ilmu Sosial Lainya.Jakarta : PT ElexMedia Komputindo.

Zuhroh, I. (2019). The Effects of Liquidity, Firm Size, and Profitability on the Firm Value with Mediating Leverage. KnE Social Sciences, 3(13),

203.

https://doi.org/10.18502/kss.v3i13.4206 